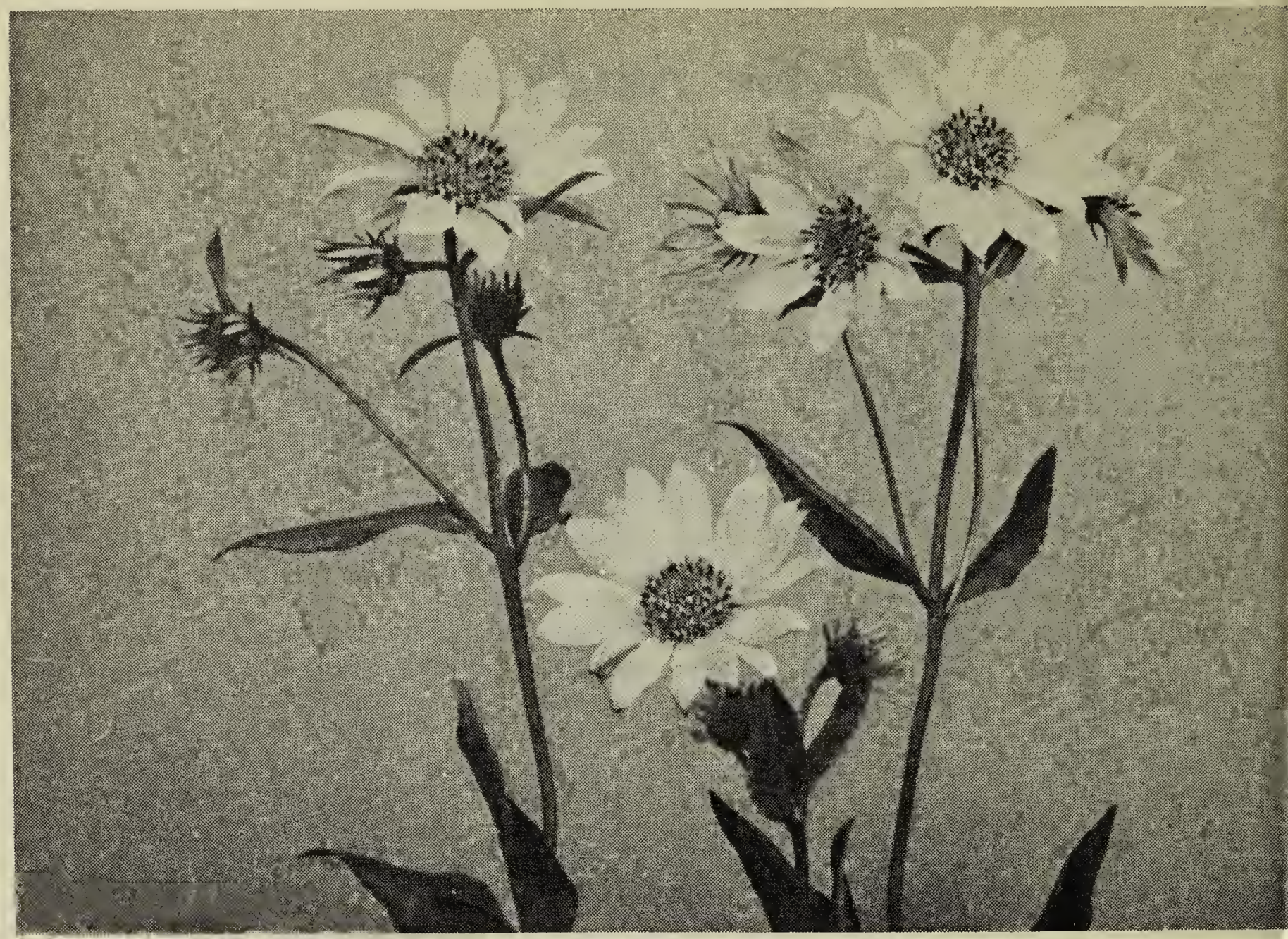

Photo by L. T. Carmichae Tuberous-rooted Sunflower, Helianthus subtuberosus

\title{
Eremopoa Persica (Trin.) Rosh. in Manitoba
}

By GEORGE A. STEVENSON.

Dominion Experimental Farm, Brandon, Manitoba

About the middle of July 1955 , while crossing the C.N.R. freight yards in Brandon I noticed a small annual grass about five or six inches high with which I was not familiar. A number of specimens were collected and in November duplicates were sent to the Division of Botany. Central Experimental Farm, Ottawa, for identification. Dr. W. G. Dore, the first botanist to examine the grass, identified it as Eremopoa persica (Trin.) Roshev. and this determination was confirmed later by Dr. N. L. Bor, Royal Botanic Gardens, Kew, England, who is familiar with the genus. Dr. J. R. Swallen, United States National Herbarium, also examined a few specimens of the original collection-Stevenson 945-and stated in a letter to Dr. Dore in December that it had not yet arrived in the United States. The Brandon collection therefore appears to be the first record of Eremopox persica growing spontaneously on the North American continent.
The station was visited again o: the 15th of June, 1956 . The mai patch covered an area of about ha. an acre and was located at the we: end of the Canadian National freigh yards in Brandon. The heaviest cor centration of plants was close to tr junction of 8 th Street and McTavis Avenue, or roughly about the cent: of the infested area. The eastern ed of the patch was fairly well define but occasional plants were found along the roadbed leading to the $\mathrm{CN}$ station, a distance of about 800 yar in a north-westerly direction.

the south plants were scattered spur tracks and around coal she which are quite common in the $d$. trict. Plants. appeared to be confin more or less to ballast and coal-il pregnated soil, but I would like confirm this observation by clo: and more detailed study during season of 1957 when I hope tl $t$ time will permit me to make a $\mathrm{m}$ ? thorough investigation.

Eremopoe persica is a weak ann 
ass native to the countries of the ear and Middle East (Asiatic Turey and Syria to the Caucasus and orthwest India), where it is fcund a sandy soils and occasionally in litivated fields and gardens. It has een introduced to several Western uropean countries and has been colcted on port and inland rubbish amps in the British Isles. Dr. G. aylor, Director of the Royal Botanic ardens at Kew, suggests that it ight be worth while searching for it those parts of Canada where olium persicum is a bad weed, since ese two grasses might have a comon origin. It may have been introuced in packing or in Russian or ersian wheats or the seed of other crop plants, or it may have escaped from the experimental plots of certain institutions where it has been used in cytological investigations. When it became established at Brandon is not known-how many years ago would be only a wild guessand where it came from is still a mystery.

Specimens have been deposited with the DAO Herbarium; the $\mathrm{Na}$ tioral Herbarium, National Museum of Canada, and the University of Manitoba. A number of specimens are preserved at Brandon and it is hoped that at least some of these will be available to those interested throughout 1957.

\section{SUMMER MEETING - CYPRESS HILLS June 15 and 16,1957}

The Saskatchewan Natural History Society invites members and friends to meet this year at the Provincial Park in the beautiful Cypress Hills. Field trips are being planned for two days. Mid-June may still be cool in the high altitudes of the Cypress Hills bring warm clothing.

RATES AND FACILITIES: Lodge rooms ( 1 bed $)-1$ person, $\$ 2,00$; 2 persons, $\$ 3.00$.

Cabins (L.H.K.), Non-modern-2-3 persons, $\$ 3.50 ; 4-6$ persons, $\$ 4.50$. Modern-4 persons, $\$ 6.50-\$ 8.00 ; 4-6$ persons, $\$ 8.00-\$ 9.00$.

Meals served in Chalet. RESERVATIONS SHOULD BE MADE EARLY. Write-

F. G. Walker, Manager, Cypress Hills Prov. Park, Maple Creek, Sask. Please mention the Society when making reservations.

\section{till More Interesting Cypress Hills Plants}

By ARCH C. BUDD, Swift Current

In this issue we can consider two ore plant species for which the only skatchewan locale is the Cypress ills. Both of these are Cordilleran mountain species and are found the eastern Rockies. The Rhomid-leaved Saxifrage (Saxifraga omboidea Greene) is quite rare re and is found on exposed grassnd at an altitude of over 4,000 feet. generally grows to a height of om 5 to 8 inches and bears a cluster basal, fleshy, rather thick, darkeen leaves, usually from $1 / 2$ to $1 \frac{1 / 2}{2}$ ches long. The leaves are ovate, unded at the apex and somewhat untly toothed and the blades are nerally contracted to an almost uncate base and then are decurrent, continue down the stalk. A glandular-hairy scape or stem from 4 to 12 inches high, arising from the rootcrown, bears the inflorescence. The flowers are white, about $\because 11 ;$ of an inch in diameter, arranged in a compound cyme or several cymules, each with a small bract below. The fruits are small follicles which open with spreading tips to release the seeds. This species is also called Micranthes rhomboidea (Greene) Small and has also been placed by some authorities as Saxifraga nivalis L. the European Alpine Saxifrage. It is found throughout the Rocky Mountains from southern Alberta to Arizona.

The second plant is the White Hawkweed (Hieracium albiflorum Hook.), a member of the Liguliflorae 